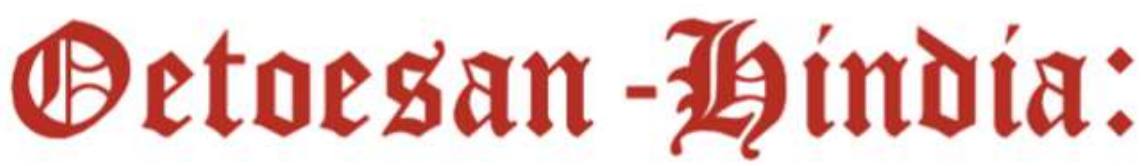 Telaah Pemikiran Kebangsaan
}

Volume 1 No 2 Tahun 2019 Hlmn. 79-84

Artikel Masuk: 10 Desember 2019 | Artikel Diterima: 31 Desember 2019

\section{Penerapan bagi hasil antara sopir bus dengan toko oleh-oleh malang}

Nisa Fardani ${ }^{\text {a1 }}$, Annisaun Nafi'ah ${ }^{\text {b2 }}$, Galang Sirendra Putra ${ }^{\text {c3 }}$, Sonia Catur Kurniawan ${ }^{\mathrm{d} 4}$

abcd Universitas PGRI Madiun, Jl Setia Budi no 85 Madiun, Indonesia, 63118

1* nisafardani@gmail.com, ${ }^{2}$ annisaunnafiah80@gmail.com,

${ }^{3}$ sonykurniawan939@gmail.com, ${ }^{4}$ gsirendra@gmail.com

*surel korespondensi: nisafardani@gmail.com

\begin{abstract}
Abstrak
Penelitian ini bertujuan untuk mengetahui penerapan bagi hasil yang di lakukan toko oleh-oleh dengan perusahaan bus pariwisata. Penelitian ini di lakukan karena adanya keunikan bagi hasil oleh dua perusahaan yang salah satunya tidak memiliki modal sama sekali dalam perusahaan dagang namun bisa mendapatkan laba. Data yang diperoleh dianalisis menggunakan metode deskriptif kualitatif tempat penelitian di lakukan pada agen bus pariwisata TS. Sumber data yang di gunakan dalam penelitian ini adalah data primer. Hasil penelitian ini adalah perjanjian bagi hasil tersebut dilakukan atas dasar saling percaya dan kedermawanan pemilik toko oleh-oleh.
\end{abstract}

Kata Kunci: Bagi hasil; Sopir bus; Toko oleh-oleh khas Malang

\begin{abstract}
This study aims to determine the implementation of revenue sharing in a souvenir shop with a tourism bus company. This research was conducted because of the uniqueness of profit sharing by two companies, one of which has no capital at all in a trading company but can make a profit. The data obtained were analyzed using a qualitative descriptive method where research was conducted on the TS tourism bus agent. The data source used in this study is primary data. The results of this study are that the profit sharing agreement is made on the basis of mutual trust and the generosity of the souvenir shop owner.
\end{abstract}

Keywords: Revenue sharing; Bus driver; Souvenir shop typical Malang

Penerapan praktik akuntansi tergantung pada sosial dan budaya dimana akuntansi tersebut diterapkan. Pada setiap lingkungan sosial dan budaya yang berbeda memiliki ciri khusus dalam penerapan akuntansinya. 
Perbedaan penerapan tersebut dikarenakan kebutuhan informasi setiap kegiatan usaha berbeda-beda. Salah satu praktik akuntansi yang memiliki nuansa lokal yaitu akuntansi bagi hasil.

Bagi hasil banyak di terapkan di Indonesia baik dalam sektor pertanian, peternakan maupun pariwisata. Setiap daerah memiliki sistem bagi hasil yang berbeda-beda terutama bagi hasil yang masih menggunakan praktik tradisional. Salah satu contohnya adalah sistem bagi hasil di bidang peternakan antara pemilik hewan ternak dengan orang yang memelihara hewan ternak yang biasa disebut dengan sistem gaduh. Selain di bidang peternakan ada pula sistem bagi hasil di bidang pertanian yaitu si pemilik lahan menyiapkan lahan kepada penggarap sawah yang nantinya hasil produksi tersebut akan dibagi antara pemilik lahan dengan penggarap sawah. Salah satu kota di wilayah Jawa Timur yaitu kota Malang terdapat berbagai macam destinasi wisata dan destinasi kuliner yang juga terdapat praktik akuntansi bagi hasil yang disesuaikan dengan budaya yang ada.

Di kota Malang terdapat banyak toko oleh-oleh yang menjual aneka makanan khas Malang salah satunya toko ADA. Toko ADA merupakan salah satu dari sekian banyak toko oleh-oleh yang ada di kota Malang. Toko ADA menjual berbagai macam oleh-oleh khas Malang seperti aneka keripik buah, dodol buah, coklat, dan lain sebagainya. Sejalan dengan berkembangnya sektor wisata yang ada di kota Malang yang menarik minat wisatawan maka semakin meningkat pula omzet penjualan toko oleh-oleh ADA. Untuk meningkatkan omset penjualan, toko ADA menerapkan strategi bisnis bekerja sama dengan sopir bus pariwisata dengan sistem bagi hasil. Hal tersebut tentunya memberikan keuntungan bagi toko ADA juga kepada sopir bus pariwisata.

Berdasarkan penelitian yang dilakukan oleh Simatupang Pantjar dkk,memperoleh hasil bahwa masyarakat Bali berpendapat bahwa sistem gaduhan sapi tradisional tersebut lebih baik daripada pola gaduhan modern seperti PIR karena lebih adil, lebih kooperatif, personal dan transparan (Simatupang, J., \& Togatorop, 2016). Selain itu penelitan lain yang dilakukan oleh Kamil Malik Mochammad dkk, memperoleh hasil bahwa sistem bagi hasil petani penyakap yang terletak di Desa Krai Kecamatan Yosowilangun Kabupaten Lumajang masih bersifat tradisional dan sederhana. Sistem tersebut merupakan salah satu bentuk dari perjanjian tidak tertulis yang sifatnya cenderung seadanya sesuai dengan adat dan kebiasaan (Malik, Wahyuni, \& Widodo, 2018).

Berdasarkan uraian di atas, peneliti tertarik untuk meneliti secara mendalam mengenai pencatatan dan sistem bagi hasil antara sopir bus pariwisata dan toko oleh-oleh ADA di Malang yang sudah berjalan lama sebagai suatu strategi bagi pengelola bisnis kuliner oleh-oleh untuk meningkatkan omset penjualan dengan melakukan kerjasama bagi hasil dengan sopir bus pariwisata, oleh karena itu penulis mengambil judul "Penerapan Bagi Hasil Antara Sopir Bus Dengan Toko Oleh-oleh Malang". 
Tujuan dari penelitian ini adalah untuk mengetahui sistem bagi hasil yang selama ini diterapkan antara toko oleh-oleh ADA dengan sopir bus pariwisata. Apakah sistem bagi hasil yang diterapkan dapat memberikan keuntungan bagi sopir bus pariwisata dan apakah keuntungan tersebut sesuai dengan yang diharapkan oleh sopir bus pariwisata.

\section{METODE}

Metode yang diterapkan dalam penelitian ini adalah metode penelitian deskriptif kualitatif. Tempat penelitian dilakukan di Agen Bus Pariwisata TS, sedangkan waktu penelitian dilakukan mulai bulan Desember 2019 Hingga Januari 2020. Sumber data yang digunakan dalam penelitian ini adalah data primer, yaitu data yang diperoleh langsung dari pengumpul data. Teknik pengumpulan data yang digunakan adalah melalui studi pustaka dan wawancara. Penulis mencoba mencari literatur mengenai sistem bagi hasil, selain itu juga melakukan wawancara dengan informan yaitu sopir bus pariwisata yang bekerjasama atau yang melakukan bagi hasil dengan toko oleh-oleh ADA.

\section{HASIL DAN PEMBAHASAN}

Kebijakan bagi hasil. Menurut Wikipedia, bagi hasil merupakan suatu bentuk skema pembiayaan yang mempunyai ciri-ciri yang berbeda dengan bunga. Dari pemahaman penulis, bagi hasil sangat menguntungkan baik bagi pihak yang memiliki bisnis/entrepreneur maupun pihak yang diajak bekerja sama bagi hasil. Di dalam bagi hasil perlu dibentuk skema perjanjian yang jelas agar bagi hasil yang dilakukan tidak menyalahi aturan serta pihak-pihak yang terlibat di dalamnya tidak ada yang merasa dikecewakan. Dalam hal ini penulis menanyakan kepada informan yaitu Bapak Rizal sebagai sopir bus yang melakukan kerja sama bagi hasil dengan toko oleh-oleh tersebut. Ketika kami menanyakan tentang bagaimana kebijakan bagi hasil yang diterapkan beliau menjawab

"Saya mendapatkan bagi hasil itu sebesar 10\% total belanja rombongan yang saya bawa, jadi misalkan rombongan saya total belanjanya $R p$ 1.000.000,- saya diberi uang $R p$ 100.000,dari pemilik toko tapi biasanya paling sedikit rombongan yang pernah saya bawa total belanjanya $R p$ 5.000.000,00 jadi ya lumayan hasilnya, selain saya dapat gaji dari agen bus saya juga dapat ceperan dari toko tersebut".

Kemudian kami menanyakan lebih lanjut apakah uang bagi hasil tersebut juga diberikan kepada agen bus, beliau menjawab

"ya, uang itu diberikan pemilik toko di dalam amplop nantinya amplop tersebut saya berikan kepada bos saya kemudian 50 dari uang tersebut diberikan kepada saya." 
Berdasarkan wawancara bagi hasil yang penulis lakukan kepada sopir bus pariwisata, bagi hasil yang diberikan oleh pemilik toko oleh - oleh kas malang kepada sopir bus pariwisata yaitu sebesar $10 \%$ dari seluruh total penjualan dari pembeli yang di bawa oleh sopir bus pariwisata tersebut. Dari $10 \%$ yang di dapat oleh spir bus tersebut dibagi lagi kepada pemilik agen bus, yaitu sebesar 50\%. Jadi sopir bus tersebut menerima 50\% dari hasil 10\% yang di dapat dari toko oleh - oleh tersebut. Lalu dari 50\% yang di dapat sopir bus tersebut di bagi ke pada kru bus.

Perjanjian bagi hasil atas dasar saling percaya dan kedermawanan. Dalam melakukan perjanjian bagi hasil tentunya ada ketentuan-ketentuan yang harus dipatuhi oleh pihak-pihak yang bekerja sama. Perjanjian adalah suatu peristiwa yang mana terdapat satu pihak dengan pihak lainnya saling bernjanji untuk melaksanakan suatu hal, dalam hal ini perjanjian yang dimaksud adalah perjanjian bagi hasil. Jenis-jenis perjanjian ada yang berupa perjanjian tertulis (formil) maupun perjanjian tidak tertulis (non formil). Perjanjian tertulis harus ditaati oleh pihak-pihak yang menandatangani surat perjanjan, sedangkan perjanjian tidak tertulis sifatnya lebih fleksibel atas dasar kepercayaan satu sama lain.

Penulis melakukan wawancara kepada informan yaitu sopir bus tentang perjanjian bagi hasil yang dilakukan beliau menjawab

"Bagi hasil ini perjanjiannya tidak ada hitam di atas putih melainkan langsung negosiasi dengan pengurus toko tersebut kemudian kami meminta persetujuan dari agen bus, perjanjian kami atas dasar saling percaya, tapi resikonya kalau rombongan yang kami bawa belanjanya hanya sedikit, pihak toko juga tidak mau memberikan uang kepada kami, jadi kami harus pandai-pandai mempromosikan barang dagangan yang ada di toko tersebut".

Berdasarkan hasil wawancara tersebut dapat disimpulkan bahwa tidak ada perjanjian hitam di atas putih pada ketentuan bagi hasil yang dilakukan. Ketentuan nya hanya dari obrolan dari sopir bus kepada pemilik toko oleh oleh kemudian sopir bus membantu mempromosikan toko oleh - oleh kepada rombongan yang dibawa agar mereka mau membeli oleh-oleh di toko tersebut.

Keuntungan dari bagi hasil bukan hanya dinilai secara meteri. Setiap kegiatan bisnis yang dilakukan oleh pengusaha identik dengan harapan keuntungan, begitupula kegiatan bagi hasil. Bagi hasil dapat diartikan membagi hasil. dengan bagi hasil pemilik usaha membagikan sebagian hasilnya kepada pihak yang diajak kerjasama dalam hal ini sopir bus. Bagi hasil ini tidak hanya memberikan keuntungan kepada pemilik usaha namun juga kepada sopir dan agen bus. 
Untuk mengetahui seberapa besar keuntungan yang diperoleh dari bagi hasil tersebut, kami melakukan wawancara kepada sopir bus tentang keuntungan apa yang diperoleh dari perjanjian bagi hasil tersebut, beliau menjawab sebagai berikut

"Keuntungan yang kami peroleh ada 2 yang pertama jelas keuntungan berupa uang, yang ke dua keuntungan berupa barang. Jadi selain kami diberi uang pihak toko juga memberikan kami oleh-oleh secara geratis dan lumayan banyak, pemilik tokonya memang dermawan sekali. Kalau untuk nominal uangnya memang tidak terlalu banyak karena masih dibagi lagi dengan agen bus dan dengan kru yang ikut, tapi ya tidak apa-apa yang penting kami masih untung dari perjanjian tersebut. Kalau untuk tokonya ya jelas penjualannya meningkat."

Dari wawancara tersebut penilis menyimpulkan bahwa Keuntungan untuk sopir bus sendiri yaitu menambah pemasukan karena dari kegiatan bagi hasil tersebut sopir bus menerima imbalan sebesar 10\% dari pemilik toko, lalu di bagi 50\% ke pada perusahaan bus. Selain itu sopir bus juga mendapat makanan atau oleh - oleh dari pemilik toko secara geratis atas kedermawanan pemilik toko. Keuntungan untuk pemilik toko oleh - oleh sendiri yaitu yang toko oleh - oleh nya ramai dan penjualannya meningkat. Dan toko olrh - oleh nya di promosikan oleh sopir bus tersebut.

Tata cara bagi hasil. Bagi hasil langsung di berikan di hari itu berupa uang cash, yang dapat dijelaskan sebagai berikut:

Total penjualan 1 hari dari rombongan bus: Rp. 5.000.000

Yang di terima sopir bus (10\%) : Rp. $5.000 .000 \times 10 \%=$ Rp. 500.000

Pembagian sopir bus kepada PO (50\%) : Rp. $500.000 \times 50 \%=$ Rp. 250.000

Jadi pihak toko memberikan uang sebesr $10 \%$ dari hasil penjualan oleh-oleh kepada rombongan bus tersebut. Kemudan uang yang diberikan kepada sopir bus tersebut nantinya diberikan sejumlah 50\% kepada agen bus.

\section{SIMPULAN}

Metode bagi hasil antara sopir dan pemilik toko hanya berdasarkan obrolan antara pemilik toko dan sopir saja.bagi hasil yang diberikan oleh pemilik toko sebesar $10 \%$ dari seluruh penjualan belum lagi dibagi lagi dengan pemilik perusahan bus sebesar 50\%.jadi sopir menerima 50\% dari hasil $10 \%$ dari oleh oleh tersebut. Bagi hasil antara sopir dan toko oleh oleh memberikan keuntungan antara dua belah pihak dari pihak opir tersendiri mendapatkan keuntungan dari toko sebesar $10 \%$ dari pemilik tooko lalu dibagi $50 \%$ kepada perusahaan bus, sedangkan untuk pemilik toko keuntungan penjualan meningkat. 
Penerapan bagi hasil ....

Fardani, N., Nafi'ah, A., Putra, G. S. \& Kurniawan, S. C.

\section{DAFTAR PUSTAKA}

Malik, M. K., Wahyuni, S., \& Widodo, J. (2018). Sistem bagi hasil petani penyakap di desa krai kecamatan yosowilangun kabupaten lumajang. Jurnal Pendidikan Ekonomi, 12(1), 26-32. https://doi.org/10.19184/jpe.v12i1.6466

Simatupang, P., J., E., \& Togatorop, M. H. (2016). Sistim gaduhan sapi tradisional bali: faktor pendorong, penopang dan karakteristiknya. Forum Penelitian Agro Ekonomi, 12(2), 50-55. 